\title{
CONCEPTUAL FRAMEWORK TO UNDERSTAND CONSEQUENCES OF TALL BUILDING
}

\author{
Haitham Sadek Abdullah Selim \\ Department of Architecture, Faculty of Engineering, Al-Azhar University, Cairo, Egypt, \\ E-mail: haitham.selim@gmail.com
}

\begin{abstract}
:According to Egyptian prime minister's declaration, Egypt will enter the world of skyscrapers, According to Forbes magazine, Egypt will construct Africa's tallest skyscraper as part of the new administrative capital project. The new building will be worth a whopping US\$ $3 \mathrm{bn}$.In the same time, we are facing issues of sustainability which must be taken consideration while the official authority adopts this new trend. There are a many of important factors to consider during a design process of a tall building which need to be examined from a wider urban scale to a narrower architectural scale. as such location and site selection, land-use, integration of landscape elements, the use of natural energy resources (wind, sun, vegetation.), the livable urban areas and building areas and nodes (plazas, innerouter courtyards of the building, service floors), transportation, façade design, material usage. Compatibility between a building and its environment is a significant architectural conversation that should be assessed and evaluated together when trying to find solutions through sustainable architectural design considerations. This paper is aimed to argue the relation between tall buildings and the built environment from the sustainable point of view. Nowadays, sustainable design is being implemented worldwide, it has become a necessity, the international community is divided as to sustainability credentials of tall buildings, there are those who defend the position that densely populated city centers with tall buildings are inherently sustainable, while others believe that the high amount of energy embodied in tall buildings is the indicator of unsustainability.
\end{abstract}

KEYWORDS: Tall Building- New Technology -Sustainability - Urban Future - Social Impacts.

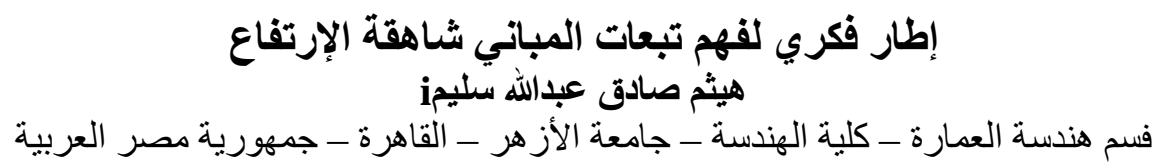

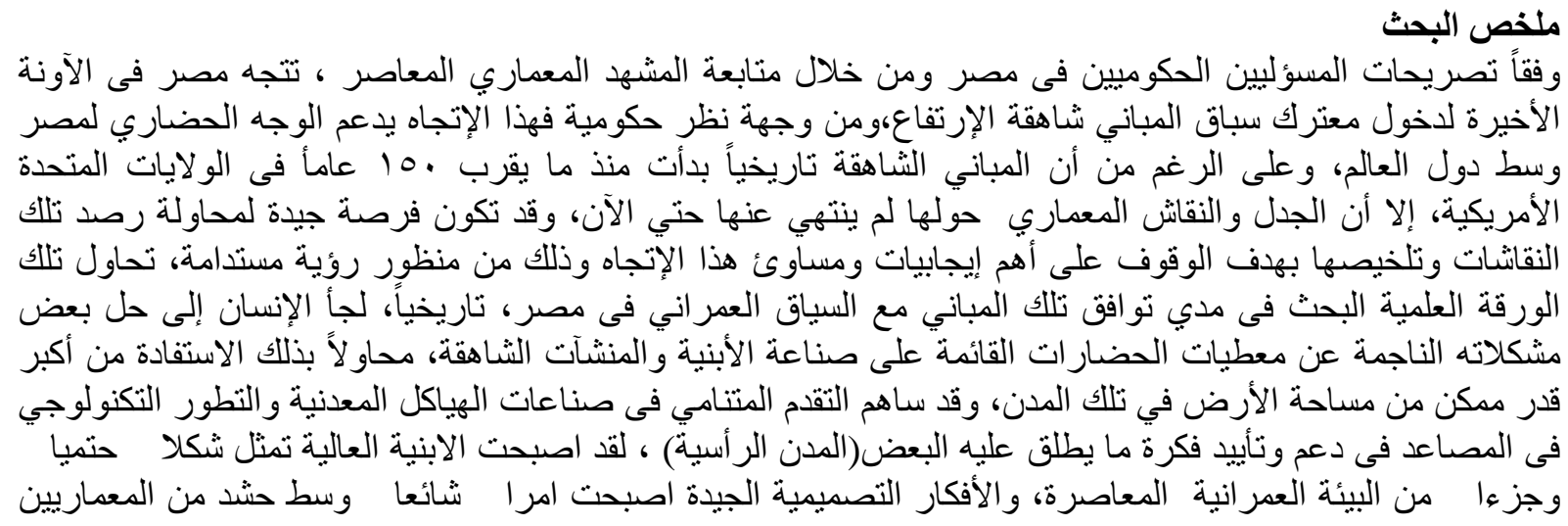




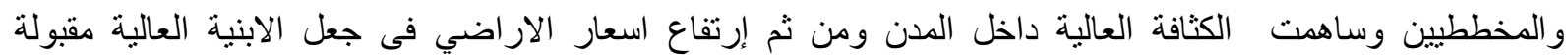

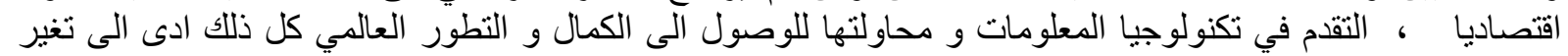

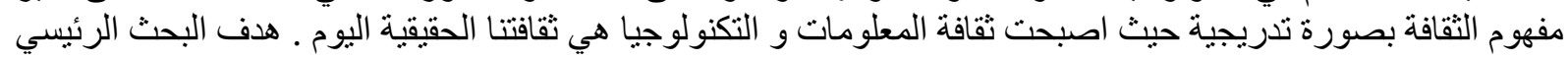

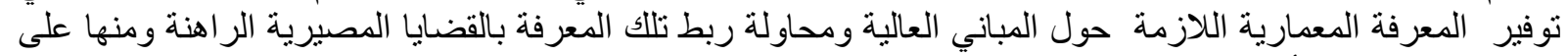

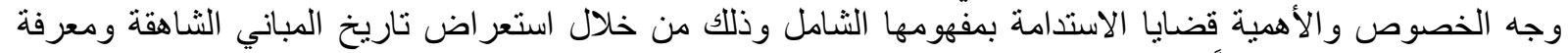

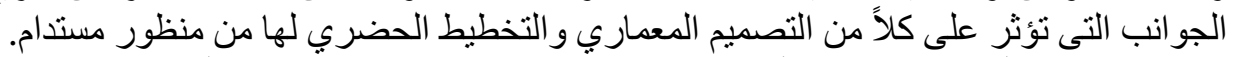

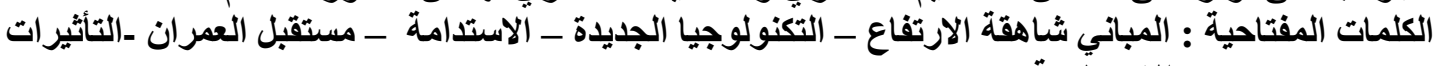
الاجتمأعية

\section{Tall buildings definition}

The word "skyscraper" or tall building is a relative term for a building which seems to reach the sky. For example, a building of only 30 floors may be considered a skyscraper if it protrudes above its built environment and changes the overall skyline. In other words, a 30-story building can be called a skyscraper in predominantly lowrise cities, whereas the same building may not be necessarily called a skyscraper in cities such as New York and Hong Kong. It is generally believed that this term originated from the mast of a ship "scraping" the sky in the wind, as

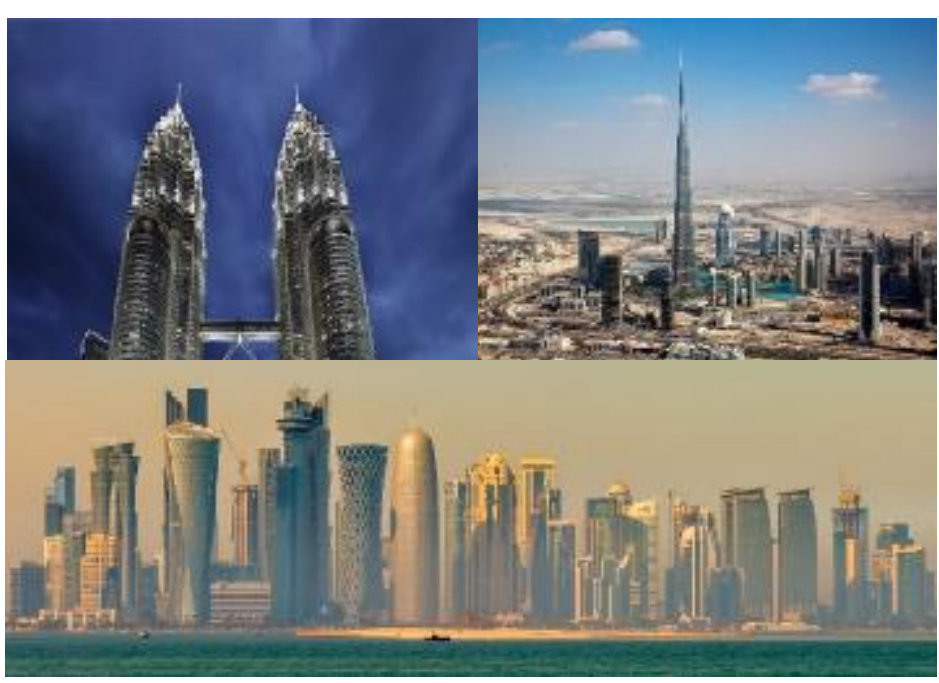

Figure 01 Since the end of the last century, Asia and the Arabic region have constructed a large amount and the tallest high-rises in the world.( https://edition.cnn.com) used by U.S. journalists in the $19^{\text {th }}$ century. The Emporis defines a "skyscraper" as "a multistory building whose architectural height is at least 100 meters" (Günel \& Ilgin, 2014) it is clear that by increasing density - the number of people per unit area - many economic, environmental and social benefits can be realized. The most prominent tall buildings are called ' high-rise buildings' in most countries and 't ower blocks' in Britain and some European countries. The terms do not have internationally agreed definitions." (Craighead,

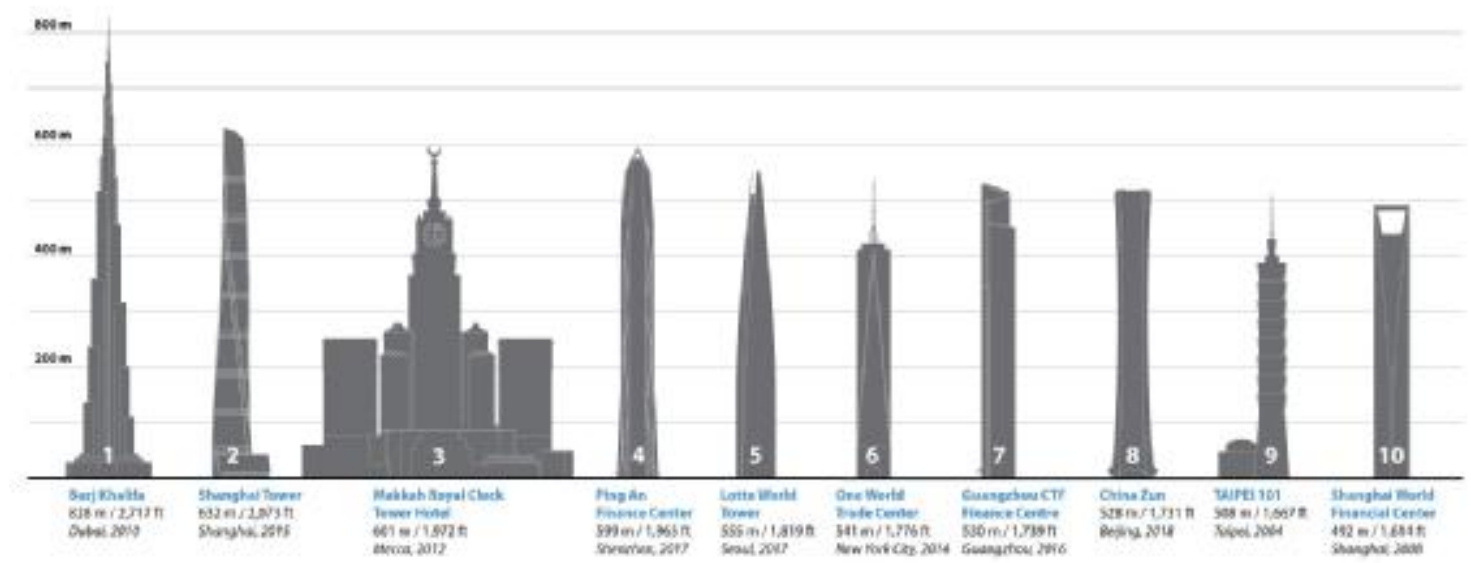

Figure 02 Height to Architectural Top method ...the architectural top of the building, including spires, but not including antennae, signage, flagpoles or other functional-technical equipment. This measurement is the most widely utilized and is employed to define the Source: (CTBUH rankings of the "World's Tallest Buildings"). 
2009) However, a high-rise building can be defined as follows:

- "Any structure where the height can have a serious impact on evacuation "( The International Conference on Fire Safety in High-Rise Buildings ) .(Craighead, 2009)

- For most purposes, the cut-off point for high-rise buildings is around seven stories. Sometimes, seven stories or higher define a high-rise, and sometimes the definition is more than seven stories. Sometimes, the definition is stated in terms of linear height (feet or meters) rather than stories. (Hall Jr, 2005)

- Generally, a high-rise structure is considered to be one that extends higher than the maximum reach of available fire-fighting equipment. In absolute numbers, this has been set variously between 75 feet (23 meters) and 100 feet (30 meters), "(Knoke, 2006) or about seven to ten stories (depending on the slab-to-slab distance between floors).

The Council on Tall Buildings and Urban Habitat (CTBUH) of the USA defines tall buildings in three ways: "architectural height excluding technical equipment such as antennas and flagpoles; height from the ground to the highest flooring; and height from the ground to the highest point of the structure including technical equipment such as antennas and flagpoles(A. B. Gültekin \& Yavaşbatmaz, 2013). also, ASHRAE Technical Committee TC 9.12, Tall Buildings, defines a tall building as one whose height is greater than $91 \mathrm{~m}$. The Council on Tall Buildings and Urban Habitat defines a tall building as one in which the height strongly influences planning, design, or use(Chidiac, Catania, Morofsky, Foo, \& Buildings, 2011)

\section{Types of High-Rise Buildings}

There are different types of high-rise buildings classified according to their primary use. This book addresses the following ones:

1. Office buildings. An office building is a "structure designed for the conduct of business, generally divided into individual offices and offering space for rent or lease." (Van Horne \& Wachowicz, 2005)

2. Hotel buildings. "The term ' hotel' is an all-inclusive designation for facilities that provide comfortable lodging and generally, but not always food, beverage, entertainment, a business environment, and other ' away from home' services. "(Beaudry, 1996) There are also hotels that contain residences. Known as hotel-residences, this type of occupancy is later addressed in mixed-use buildings.

3. Residential and apartment buildings. A residential building contains separate residences where a person may live or regularly stay. Each residence contains independent cooking and bathroom facilities and may be known as an apartment, a residence, a tenement, or a condominium. An apartment building is "a building containing more than one dwelling unit." "Apartment buildings are those structures containing three or more living units with independent cooking and bathroom facilities, whether designated as apartment houses, ... condominiums, or garden apartments. "(Cote, 2008)

4. Mixed-use buildings. A mixed-use building may contain offices, apartments, residences, and hotel rooms in separate sections of the same building. Hotel residences are another type of mixed-use occupancy.

\section{History of Tall buildings}

Historically, the ambition to reach the sky is has been reflected in every culture, particularly in ceremonial and symbolic buildings such as the Tower of Babylon, the Pyramids in Egypt, Buddhist Temples, cathedrals and mosques. The industrial revolution contributed a functional aspect, where block buildings of two to four floors were built next to factories to house laborers.

Cities were growing quickly at the turn of the twentieth century, and as a result architects began

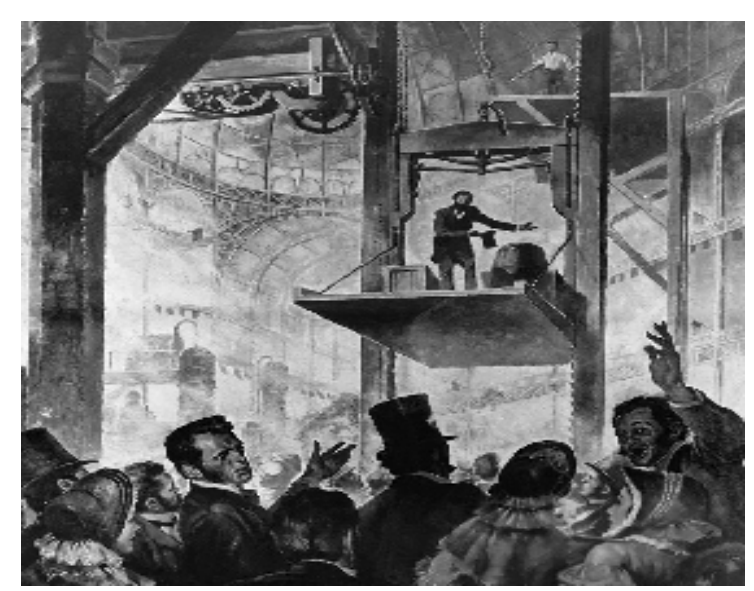

Figure 03 Otis Publicly Demonstrates the World's First Safety Elevator. In 1854, Elisha Graves Otis at the Crystal Palace Exposition in New York .

Source :(https://en.wikipedia.org/wiki/Elisha Otis) 
to design buildings with a vertical orientation. From technical point of view, high rise had become possible at the end of the nineteenth century due to several technical inds and improvements in building techniques, such as steel and armed concrete simplified high rise and the introduction of the elevator safety braking system in 1853 made high rise practically useful(Thornton et al., 2011). Tall buildings can be seen all over the world, they can be used to show of wealth and power, religious beliefs or to push the boundaries of engineering. The ancient Egyptians built the pyramids nearly 5000 years ago as tombs for their Pharaohs and their consorts, and to this day they are still standing as some of the oldest highrise structures in the world. Likewise the Gothic
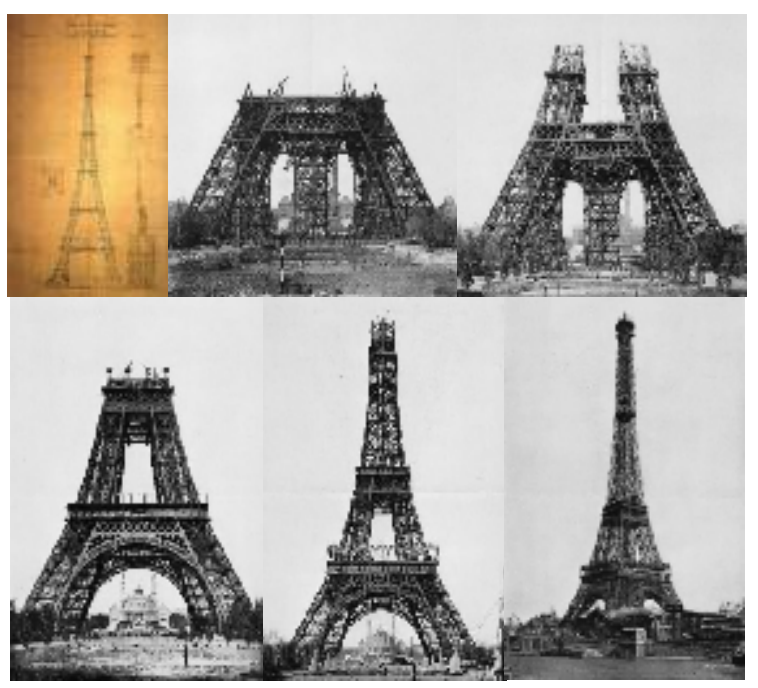

Figure 04 Eiffel Tower : is a wrought-iron lattice tower on the Champ de Mars in Paris, France. It is named after the engineer Gustave Eiffel, whose company designed and built the tower. Constructed from 1887 to 1889 .Source:(Wikipedia) cathedrals of Europe were the skyscrapers of medieval time, rising far above anything else in Europe, however all the early high-rise structures have one thing in common, they have a structural system made of masonry which limited the building height due to the high self-weight of the material (Craighead, 2009). People had been building hoists of various kinds for hundreds of years. And they all had the same serious defect: they plunged to the bottom every time the lifting cable snapped". the 'vertical transportation industry' began in ancient Greece. In 236 BC, mathematician Archimedes built a hoisting device using ropes and pulleys. A few centuries later, Roman gladiators and lions rode primitive elevators to reach the floor of the Coliseum. Donkeypowered lifts were the rage of the Middle Ages.... By the 1800s, steam-powered hoists began transporting miners to and from underground veins of ore" (Craighead, 2009) In 19th century many of American architects went to Paris for training and education and brought back with them ideas that influenced their architecture. In Paris, the Eiffel Tower, at 300m (984 ft) in 1889 , was surely a catalyst for new heights with its remarkable architectural qualities and became known as an engineering masterpiece. The U.S. also exported cultural and architectural ideas and developments to Europe that included the skyscraper, a clearly American innovation with its beginning in Chicago. (Beedle, 1988) Before then, buildings could not be built taller than five or six stories, because there was no way to transport people and objects to the higher floors; the invention of the elevator allowed buildings to rise beyond those limitations.

Referring to comments made by Otis Company officials, “Otis hadn't invented the first hoist. But he had invented the first 'safe' hoist. In 1853, Elisha Graves Otis introduced the world's first safety elevator in Yonkers, New York. This invention changed the shape of the modern world(Swarr, Legarth, \& Huang, 1999). In the late-nineteenth century, engineers began experimenting with new ways of using iron and steel. Traditionally these

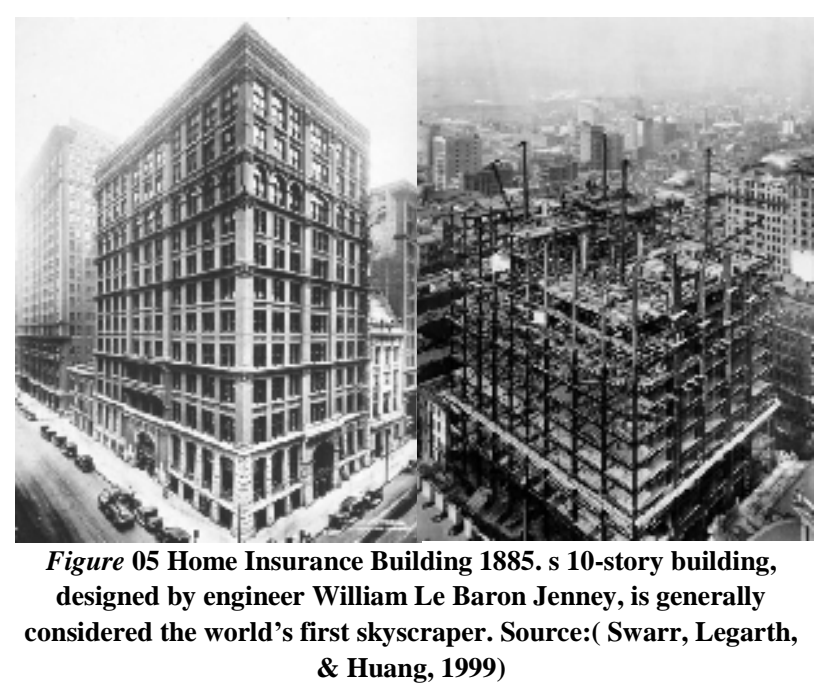


materials were used for transportation structures such as bridges, train tracks, and railway stations. Through trial and error, engineers developed steel skeletons made of vertical columns and horizontal beams to support tall buildings(Khan, 1972). The Home Insurance Building (1884-85) in Chicago was the first to be constructed with a complete steel-frame structure. These design innovations were also used in the construction of famous structures such as the Eiffel Tower, the Statue of Liberty, and the Brooklyn Bridge(Condit, 1973). The two sectors that dominated the first generation of tall buildings were newspapers and insurance corporations, both seeking image and power in the city. Domosh figured out the symbolic role of skyscrapers as a reflective image of economic paradigm changes: "These first tall buildings need to be understood as attempts by this new economic class to fulfill two parallel goals - to find appropriate expression for its new power and to legitimize that power by placing it within the constructs established by the more traditional elite, thereby conveying a civic as well as a commercial message." (Domosh, 1988).

Many specialists classified the tall building as an "industrial mass production", The idea of using industrial mass-production building systems as a basis for design has its origins in the 1920s (Scott, 2007).Frank Lloyd Wright's design for the S.C. Johnson and Son Office Building in Racine, Wisconsin of 1939 is an example of design integration versus standard practices of construction. Wright, like many architects, thought that a functional building should be tightly integrated and, therefore, would be less expensive. In an integrated building, in which the separate systems are tightly interlocked, more functions can be performed by each element. In modern construction, elements tend to be independent and specialized rather than monolithic, integrated, and multifunctional. This is especially true in largescale buildings like high-rises where specialization of labor and materials in the building industry requires a

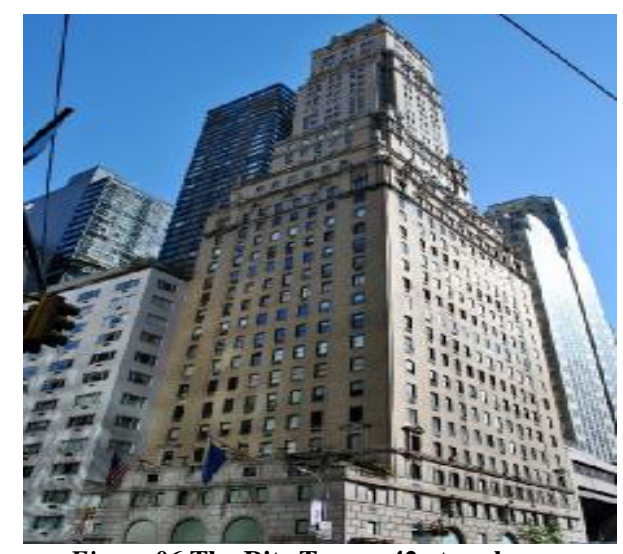

Figure 06 The Ritz Tower 42-story luxury residencial building located at 465 Park Avenue on the corner

of East57thStreet in Midtown Manhattan, New York City. Source:

(https://en.wikipedia.org/wiki/Ritz_Tower) high level of organization and coordination among the suppliers and fabricators.(Giedion, 1971).

Changes in living patterns in the twentieth century have bought new demand for new housing solutions as well as a desire to limit the spread of urban areas into agricultural lands, for that reason, tall building may therefore be a logical progression but in terms of serving the needs of a rising population, the high-rise experience has not always been positive. In Denmark, England, Germany and even the U.S., experiments in the seventies and eighties showed that living vertically may not meet the expectations of the residents used to living at ground-level; in numerous cases, authorities were forced to demolish residential towers built only a few years earlier. For many years, the United States was the leading country when it came to highrise buildings, both in the amount of buildings being built and the maximum height. Since the end of the last century, Asia and the Arabic region have constructed a large amount and the tallest high-rises in the world. These have included the Petronas Towers in Malaysia, Taipei 101 in Taiwan and Burj Khalifa in Dubai(Craighead, 2009).

\section{Tall building and population increase}

The dramatic increase of populations around the world, and the migration from rural to urban areas, give reasonable justification for building tall. Tall buildings promise to achieve a greater level of density, to reduce building footprints in favour of public space, and to encourage use of public transit - all of which will help cities to grow sustainably in an era of 
climate change, resource scarcity and dramatic urbanization. Currently, the concept of vertical living and working has been hailed as a solution to facilitate fast growth and urbanization of cities worldwide(Drew, Nova, \& Fanning, 2014) At the beginning of 2015, the global population was around 7.2 billion people(Bureau, 2013) Tall buildings can address many of the environmental issues facing cities by providing high-density, efficient buildings that link to public transportation systems and offer the type of amenities demanded by tenants(Wood, 2013). It is projected that by 2030, 5 billion people will live in urban areas throughout the world (United Nations, 2001). Whereas 30 per cent of the world population lived in urban areas in 1950, the proportion of urban dwellers climbed to 47 per cent in 2000 and is projected to rise to 60 per cent by 2030 .

According to united nations the rate of population growth remains especially high in the group of 47 countries designated by the

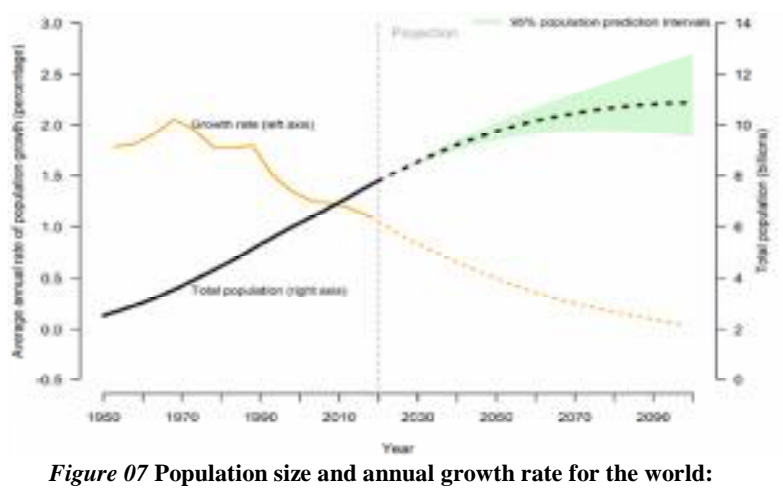
estimates, 1950-2020, and medium-variant projection with 95 per cent prediction intervals, 2020-2100 Population growth continues at the global level, but the rate of increase is slowing, and the world's population could cease to grow around the end of the century (Data source: United Nations, Department of Economic and Social Affairs, Population Division (2019). Source: (World Population Prospects 2019). United Nations as least developed, including 32 countries in sub-Saharan Africa. With an average growth of 2.3 per cent annually from 2015 to 2020, the total population of the least developed countries (LDCs) as a group is growing 2.5 times faster than the total population of the rest of the world. Although the growth rate of LDCs is projected to slow in the future, the population of this group of countries is projected to nearly double in size from 1 billion inhabitants in 2019 to 1.9 billion in 2050 , and to increase further to 3.0 billion in 2100 .

\section{Tall buildings: critique point of view \\ Social and sociolegal side}

the literature suggests that high-rises are less satisfactory than other housing forms for most people, that they are not optimal for children, that social relations are more impersonal and helping behavior is less than in other housing forms, that crime and fear of crime are greater (Gifford, 2007). In the same context, early in 1967, Hans Blumenfeld in his important work The Modern Metropolis disapproved tall buildings because they damage the historic fabric of cities (Blumenfeld, 1967). Posteriorly Christopher Alexander and colleagues in their seminal book A Pattern Language rejected the high-rise city altogether as a viable human habitat. According to Alexander he argued that, tall buildings have no genuine advantages, except in speculative gains for banks and land owners, Alexander added that " tall buildings is not cheaper, they do not help create open space, they destroy the townscape, they destroy social life, they promote crime, they make life difficult for children, they are expensive to maintain, they wreck the open spaces near them, and they damage light and air and view. In Pattern 21: FOUR-STORY LIMIT in his outstanding and famous book "the pattern language" , he said "There is abundant evidence to show that high buildings make people crazy. Therefore, in any urban area, no matter how dense, keep the majority of buildings four stories high or less. It is possible that certain buildings should exceed this limit, but they should never be buildings for human habitation".(Alexander, 1977). In the same context, James Howard Kunstler, argues that skyscrapers generate urban pathologies, they also demand lots of energy and are expensive to retrofit. Also Ken Yeang, whom consider as a leading figure on sustainable tall building developments, stated that, "At the outset, we should be clear that the skyscraper is not an ecological building type ", he argued that, tall buildings require 
excessive materials and sophisticated structural systems to build so that they are able to withstand greater wind forces that prevail at higher altitudes and they also demand greater energy to construct, operate, and costly maintenance (Yeang, 2008). Although Léon Krier, one of the most distinguished supporter of the New Urbanism movement, but he explains in his book The Architecture of Community that, buildings should have no more than five floors (Krier, 2009).

Eventually, both of the Danish architect and urban designer Jan Gehl in his book "Life Between Buildings" and "Cities for People" critiqued high-rise cities and praised low-rise ones in various parts of the world for they emphasize the value of human scale and provide abundant opportunities for healthy social interaction (J. Gehl, 2011).

According to Jeanne Gang, "The problem is that the highly visible position of the tall building in global culture has led to one-liners and symbolism in a superficial battle for identity" They have often been associated with irrelevant, ostentatious design meant to gain popularity and attention(Gang, 2008).

From social point of view, social science literature reveals that people have multiple concerns about high-rise living including suitability for family living and raising children, neighborly relationships and helpfulness, personal behavior and comfort, perception of safety, tenants' relation to outdoor spaces and connection to street life (Pruetz, 2017). In addition to , High-rises' tenants often feel that they are cooped up in finite spaces of an encapsulated world that fosters loneliness. These environments may make inhabitants also feel claustrophobic, creating a rat-cage mentality. Further, high-rise living could promote poor interpersonal relationships and weak neighborly relationships that may result in a psychological depression. In some cases, the "isolated" nature of high-rise buildings could promote crime. Further, scholars argue that low-rise living is closer to nature and facilitates a stronger community-oriented social life (Prezza, Amici, Roberti, \& Tedeschi, 2001).

According to Robert Gifford in his work "The Consequences of Living in High-Rise Buildings" he details six types of fears found in high-rise living as follows: Users worry that a family member or a loved child jumps from a window, fear masses of "strangers" that share the same building or floor, Users fear a fire that may trap them in the building, fear a devastating earthquake that will topple the building over them, users may fear becoming ill from communicable diseases generated by the masses who live there and eventually, post 9/11, high-rise residents fear that their buildings become terrorist targets. (Gifford, 2007) The collapse of the World Trade Center (WTC) on September 11, 2001 reinforced opinions of tall buildings as unsafe

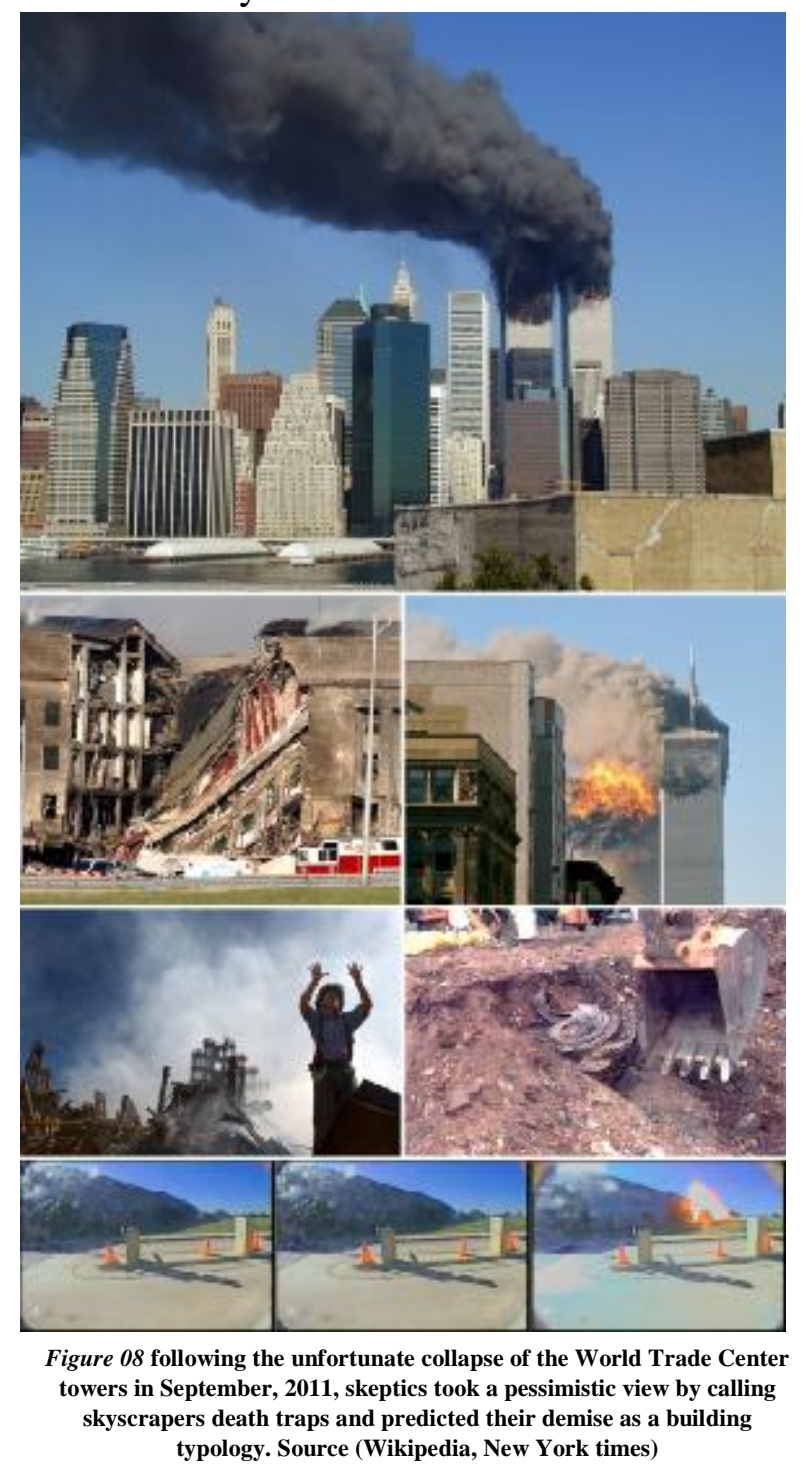


and caused some critics to conclude that this event marked the end of tall buildings.

Constantinos Doxiadis, argued that High-rise buildings work against man himself because they isolate him from others, and this isolation is an important factor in the rising crime rate, also children's suffer even more because they lose their direct contact with nature and other children's. He added that, High-rise buildings work against society because they prevent the units of social importance - the family, the neighborhood, etc., from functioning naturally and as normally as in low-rise environments (Madanipour, 2010). Many specializes argued, living in very tall buildings has many physical, mental and social implications. From a physiological point of view, any distancing from the ground impinges on balance and stability, and people who live for extended periods at high attitudes develop adaptations such as expansion of the blood-vessels, higher levels of hemoglobin and greater lung capacity(Gonçalves, 2010). Spatially and socially, a high rise building is a dead-end street (cul-de-sac). Researchers in England and Denmark have recorded the negative effects on community life of former lowrise home residents who had freedom to move around and develop relations with neighbors of their choice. Research shows that after moving to an apartment building, residents' feelings of isolation increase in direct relation to the height of the building and the number of residents it houses, result from confinement to an apartment with few outside windows (due to strong winds), categorical separation between the different floors, the number of elevators, etc. However, critics and perceptions did not impact tall building development since the past decade has witnessed an unprecedented construction boom of tall buildings around the world. (Sunder, 2004).

\section{Transportation and traffic}

Tall building can create problems, such as overcrowding around it that can decrease the quality of life unless conceived and adequately mitigated during the planning stage for the building's long term function. (Ali \& Al-Kodmany, 2012) In addition to Tall buildings increase demand on transportation and infrastructure. Possible mitigation for increased traffic includes expansion of traffic capacities on roads and at intersections and multiplication of public transit options, which require major public works and construction. Likewise, a new tall building will place additional load on the existing power grid, water supply, and sewer systems. If a tall building is built in an undeveloped area, new cost-intensive infrastructure must be provided, for that reasons, Tall buildings require exceptional fortitude from many stakeholders including property owners, developers, planners, architects, and engineers.

For that reason, traffic impact assessment studies should be required to identify its effect on the existing transportation systems.

\section{Tall buildings from economical / environmental perspective}

Tall buildings are costly for they require special engineering expertise as well as special construction equipment. They exert significant demand on infrastructure and transportation systems, and affect the historic fabric while reshaping the city skyline. Furthermore, they influence the micro-environment by casting shadows and blocking views and sun light. They also consume massive quantities of energy and require a high operational cost. For these reasons some critics have viewed tall buildings as an undesirable "urban evil" that reduces the quality of urban life. Further, following the unfortunate collapse of the World Trade Center towers in September, 2011, skeptics took a pessimistic view by calling skyscrapers death traps and predicted their demise as a building typology. Although, Tall buildings may have potential environmental advantages, such as ample access to sunlight and wind for the incorporation of solar panels and wind turbines. However, tall buildings produce adverse effects the microclimate, due to wind funneling and turbulence, which may inconvenience pedestrians around them. Also, tall buildings create overshadowing problems and cast large shadows, affecting adjacent properties by blocking sunlight. In the same context, many 
specialists argued that, Tall buildings are environmentally damaging when they fail to incorporate energy efficient design solutions in their heating, cooling, and ventilation systems. If they are unattractive, tall buildings can harm the image of a city.

\section{The Conflict With place-making}

Place-making is a concept that emerged after it became clear that it was necessary for the urban design to consider the cultural, social, economic, political and spatial factors as well as the importance of people's activities and perceptions of urban public places.

Tall buildings frequently evoke the image of a nerve-racking, workaholic business environment. In addition, in residential areas they convey the perception of living in crowded apartments that are more akin to cages than living spaces. Inhumanely high towers often shatter the human scale by dwarfing nearby public spaces and buildings, particularly those of a historic character (J. J. W. D. Gehl, 2010)Also, tall building proposals often are challenging because of their inevitable impact on the historic urban fabric.

The impact of high-rise development is critical for the conservation of the built heritage of cities , and many cities suffer from a lack of a strategic approach to managing tall buildings. Buenos Aires, Sao Paulo, and Mexico City are, Dubai, Mecca are losing their local distinctiveness and urban character through the ad hoc construction of tall buildings (Short, 2004) . Future of tall buildings should foster placemaking by relating to their specific locations, respecting the built heritage, and connecting with the socio-cultural conditions. Nowadays, the present researchers seek to assess the current situation regarding tall buildings in the developing areas of Asia and the Middle East - especially from the perspectives of

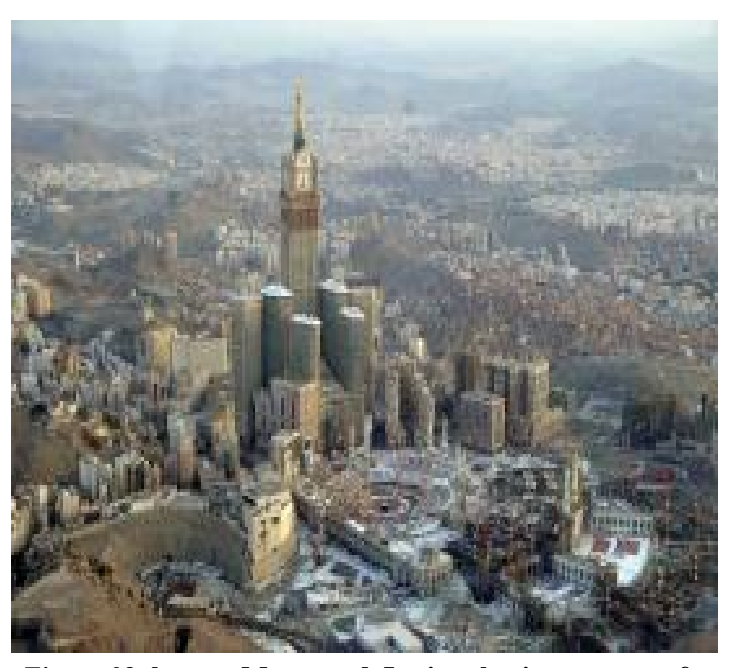

Figure 09 the new Mecca and Losing the importance of the Kaaba through skyscrapers. Source(www.britannica.com/place/Mecca) place-making, the image of a city, and identity (Sinclair \& Systems, 2015) . Design of new tall buildings should supplement, not contradiction with the historic fabric. And this is a challenge to make tall buildings support place-making concept.

\section{Tall buildings form sustainable perspective}

According to the World Commission and Environmental Development or Brundtland Report, "Our Common Future", sustainable design is an effort to meet the requirements of the present without compromising the needs of future generations by encouraging the wise and prudent use of renewable resources, alternative strategies for energy production and conservation, environmentally friendly design, and intelligent building technology. It adds that, "Sustainable development is not a fixed state of harmony, but rather a process of change in which the exploitation of resources, the direction of investments, the orientation of technological development, and institutional change are made consistent with future as well as present needs"(Cassen, 1987) Approximately $17 \%$ of water sources, $25 \%$ of forestry products and $40 \%$ of energy sources are consumed by the building sector.(Say, Wood, \& Journal, 2008) Sustainable design of tall buildings is an approach to developing tall building sites and buildings that is less resource intensive and works to improve the economic, social, and natural environment we live in. Until recently, tall buildings have been viewed as megascale energy consumers with little regard for sustainable architecture. However, this is changing with a new generation of high-rise buildings that have been designed with energy conservation and sustainability as their principal criteria. Cities throughout the world are 
growing rapidly, creating unprecedented pressure on material and energy resources. Currently, sustainable design became a method for tall buildings to perform well in present time and future. Sustainability is handled for a long term and this situation is usually associated with the buildings' physical requirements such as; energy efficiency (energy consumption, material usage). However, the main matter is beyond technology and smart design, the creation of sustainable tall buildings, goes far beyond just energy use and even bolder environmental considerations (Oldfield, 2012) during the last five years the focus of building design has shifted from predominantly architectural and functional approaches to more exhaustive approaches putting a special emphasis on sustainability.

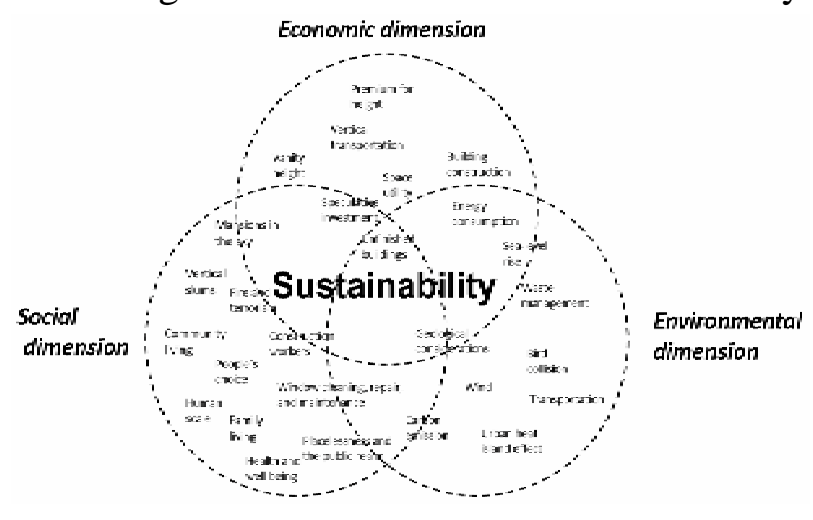

Figure $1 \cdot$. overall vision of the sustainability concept Source:( AlKodmany, K 2015)

During the past 40 years a significant realization that the current model of development is unsustainable. In other words, we are living beyond our means. From the loss of biodiversity with the felling of rainforest's or over fishing to the negative effect our consumption patterns are having on the environment and the climate. Our way of life is placing an increasing burden on the planet - this cannot be sustained." regrettably, it is a worldwide fact that we are not even meeting our current needs, let alone considering the needs of future generations. The quest to meet the goal set out by the Brutland Report is currently one of humankind's biggest concerns. Unless we start to make real progress toward reconciling the contradictions, we all, wherever we live, face a future that is much less certain and less secure than we have enjoyed over the past. A decisive move toward more sustainable development is crucial, both because it is the right thing to do, and because it is in our long-term best interests.(Sneddon, Howarth, \& Norgaard, 2006) . Sustainable design for tall buildings includes construction materials that are sensitive to the environment, reusable and renewable, that minimize energy consumption, use renewable and local resources thus reducing the use of nonrenewable natural resources, create healthy indoor areas, use solar power, natural ventilation and natural illumination, and do not require frequent maintenance and repair (A. Gültekin \& Dikmen, 2006). The fundamental core of sustainable development is about five key principles: quality of life; fairness and equity; participation and partnership; care for our environment and respect for ecological constraints - recognizing there are 'environmental limits'; and thought for the future and the precautionary principle(Kuhlman \& Farrington, 2010). The integration between a tall building and its environment is an important architectural dialogue that should be assessed and evaluated together when trying to find solutions through sustainable architectural design considerations. There are a lot of important factors to consider during a design process of a tall building which need to be examined from a wider urban scale to a narrower architectural scale. Examples that may be given for these factors are location and site selection, land-use, integration of landscape elements, the use of natural energy resources (wind, sun, vegetation.), the livable urban areas and building areas and nodes (plazas, innerouter courtyards of the building, service floors), transportation, façade design, material usage. It can be seen that, it is a must to discuss the building with other landscape parameters, in order to create healthy environments.

\section{The concept of 3Ps}

Sustainability offers an inclusive framework represented in its three conceptual pillars (the social, the economic, and the environmental) or the "3Ps" of people, profit, and the planet, 
where:"people" represents community well-being and equity ""profit" represents economic vitality; and "planet" represents conservation of the environment. These pillars or dimensions are also expressed by the "3Es" of equality, economics, and ecology or what is known as the triple bottom line (TBL or 3BL). Sustainability seeks to balance these three dimensions across geographic scales-from individual habitats to neighborhood, community, city, region, country, continent, and the planet at large - and according to both short and long-term goals. Therefore, the centrality and comprehensiveness of sustainability suggest using it as an "umbrella" term that captures a wide-spectrum of practical projects under different agendas"ecological", "environmental", "green", "social" and "economic"-which all share the common thread of reducing harmful impact on the environment while delivering economically viable, healthy, and comfortable human habitats(Milne \& Gray, 2013) .

"The green meets the blue" expression refers to how architects are incorporating sustainable design principles augmented with new materials and technology into the design of tall buildings. Green building design principles also point to resource-efficient approaches to construct a tall building that will eventually be more economical to operate. Energy conservation in tall building design has become a determinant for the building's form, expression, exterior cladding systems, nature and extent of exterior glazing, and the size and location of atrium. (Al-Kodmany, 2015)

\section{Green or sustainable tall building ?}

The green design indicators of key sustainability concepts for this paper, have been comprised of by considering both LEED (Leadership in Energy and Environmental Design) and BREEAM (Building Research Establishment Environmental Assessment Method) requirements. furthermore, when dealing with design logistics of both a green and a sustainable building, it is inevitable to concentrate both on physical and social points in designing a tall building. therefore, site location, site organization, transportation, urban skyline, material selection and façade design, entrance floor design, vertical design and the urban microclimate are the key concepts of sustainability which will be used for this research study. These main key sustainability standards define the boundary of both physical and social parts of sustainable design for tall buildings in this paper.

\section{Green Building}

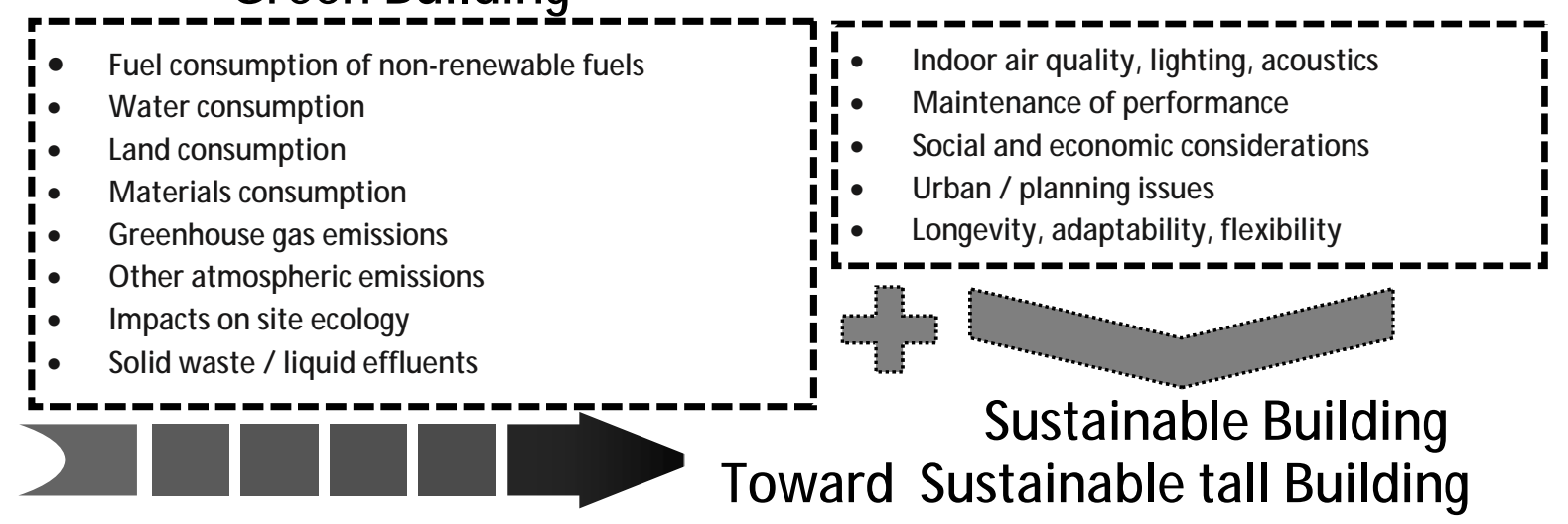

Figure 10 Green or sustainable tall building? Source :(Author 2019)

Sustainability covers social, ecologic, and economic questions. The social aspect comprises cultural considerations, comfort, social integration, health, ergonomics, and functionality The economic aspect is assessed by value-engineering and commercial departments. The ecological aspect, however, is often reduced to energy efficiency only. Ecology is thus taken into consideration but to a relatively limited degree.(Council, 2003). Over the key 
sustainability concepts, a necessary perspective is inevitably the green building and green environmental standards. The best-known standards for sustainable building design are listed by US Green Building Council - LEED (Leadership in Energy and Environmental Design) certificate' and UK Green Building Council - BREAM (Building Research Establishment Environmental Assessment Methodology). LEED and BREEAM certificates generally insist on sustainability standards of buildings regarding: location, transportation, materials and resources, water efficiency, energy and atmosphere, indoor environmental quality, neighborhood pattern and design, infrastructure, renewable energy systems, health and wellbeing, waste management, pollution. These criteria are generally physical requirements but a sustainable building has to address social concerns as well.

Larsson clarifies the difference between a green building and sustainable building; "Currently the emphasis is on 'green', focusing mainly on environmental performance and often defined in operational terms. Sustainable approach is operationally defined as including social and economic factors"(Larsson \& Environment, 2009)

The next table conclude the main indicator and c criteria ratings in order to reach tall sustainable buildings, this table based on LEED \& BREAM criteria, These criteria were developed by author through the previous literature in this paper to add the social and placemaking factors.

\begin{tabular}{|c|c|}
\hline Main Indicator & Criteria Ratings \\
\hline Sustainable Site & $\begin{array}{l}\text { Preventing pollution while construction (obligatory), the appropriate site } \\
\text { selection, obtaining optimal density in built environments and vicinity to urban } \\
\text { services, restoration of damaged sites and environmental pollutions, providing } \\
\text { easy access to public transportation systems, invention appropriate parking } \\
\text { capacity, maximizing outdoor, qualitative and quantitative management of } \\
\text { rainfall, preventing heat island in non-roofed buildings and preventing heat } \\
\text { island in roofed buildings, Reducing light pollutions. }\end{array}$ \\
\hline Water Efficiency & $\begin{array}{l}\text { Reducing water consumption (obligatory), saving water consumption of } \\
\text { irrigation systems, waste recycle by using the innovative technologies. }\end{array}$ \\
\hline Energy & $\begin{array}{l}\text { Assurance of energy systems performance accuracy in the buildings } \\
\text { (obligatory), minimum use of energy in the buildings (obligatory), preventing } \\
\text { reduction of ozone layer through cooling instruments(obligatory) optimization } \\
\text { of energy consumption in the buildings, using renewal energy resources, } \\
\text { distinguished and evaluated energy consumption in building. }\end{array}$ \\
\hline Materials & $\begin{array}{l}\text { Gathering and saving renewable material (obligatory), reuse of the building } \\
\text { with keeping non-structure elements of indoor building, managing wastes } \\
\text { produced by construction, using recycled materials, using local materials, using } \\
\text { materials with immediate recyclability. }\end{array}$ \\
\hline Indoor Air Quality & $\begin{array}{l}\text { Achieve to minimum desired air quality of indoor building (obligatory), } \\
\text { controlling the amount of tobacco smoke released of the environment } \\
\text { (obligatory), installing carbon dioxide measurement systems of building output } \\
\text { air flow, increasing ventilation system, managing the quality of indoor air } \\
\text { before operation of the building and at the time of construction, using materials } \\
\text { with less pollution (including adhesives and linings, colors and covers, roofing } \\
\text { and wooden products), controlling lighting systems, controlling heat and } \\
\text { ventilation systems, heat comfort system design, providing natural light, } \\
\text { providing appropriate view. }\end{array}$ \\
\hline Innovation & Innovation in designing with the desired LEED factors \\
\hline Regional Priorities & Importance to the local priorities. \\
\hline Place-making & $\begin{array}{l}\text { Compatibility with the historic fabric/ city image / vertical landscaping / the } \\
\text { visual impact of a tall building on the surrounding historical views or landmarks }\end{array}$ \\
\hline Social needs & $\begin{array}{l}\text { The integration of a tall building with physical and social urban environment } \\
\text { and street life/ public access through the site and existence of the pedestrian } \\
\text { areas/ the connection between public spaces with the surrounding urban places } \\
\text { existing within the tall building site// balconies and terraces/ solar shading } \\
\text { devices }\end{array}$ \\
\hline
\end{tabular}




\section{Case Study}

Hereunder a few case studies building examples are presented which represent the new generation of sustainable tall buildings that are setting trends for future projects incorporating innovations in materials and building systems. The case study examples of recent spectacular tall buildings of the 21 st century are presented.

\section{TRUMP INTERNATIONAL HOTEL AND TOWER (NEW YORK CITY)}

The Trump International Hotel and Tower is a high-rise building, located at 1 Central Park West on Columbus Circle between Broadway and Central Park West, in Manhattan, New York City. The building is 583 feet (177.6 m) tall (White, Willensky, \& Leadon, 2010).

A special feature of this building is that it is one of the largest buildings, which was partially opened to the public during construction.

This required a feat of planning, mixed-use programming, and construction with the collaboration of the owner, architect, construction manager, and the City of Chicago. The tower combines 60 floors of luxury condominium units stacked over 11 floors of hotel units, with parking spaces, and a number of amenities, including a restaurant, banquet space, health club/spa, and lounges. Such stacking of the different programs on top of one another creates an adaptable building. A main attraction of living in Trump Tower is the close-up views of the waterfront and some of Chicago's most well-known buildings. Through a series of setbacks at different heights,

the tower closely relates to its neighboring buildings like the Wrigley Building, Marina City towers, and the IBM Building. The tower's design is much influenced by the presence of water in the nearby Chicago River; for example, a $10.6 \mathrm{~m}(30 \mathrm{ft})$ high "structural glass wall, hung from the second floor, resembles a cascading wave" (Baker, James, Tomlinson, \& Weiss, 2009).

\section{BANK OF AMERICA TOWER IN MANHATTAN}

The Bank of America Tower (BOAT) at One Bryant Park is a $1,200 \mathrm{ft}(365.8 \mathrm{~m})$ skyscraper in the Midtown area of Manhattan in New York City, 2,100,000 square feet $(195,096 \mathrm{~m} 2)$ of office space, three escalators and a total of 52 elevators--50 to serve the offices and two leading to the New York City Subway's mezzanine below ground, for the 42nd Street - Bryant Park / Fifth Avenue station. The tower's architectural spire is $255.5 \mathrm{ft}(77.9 \mathrm{~m})$ tall and was placed on December 15, 2007.(Donnolo, Galatro, \& Janes, 2014) It is the second tallest building in New York, and it employs a glass curtain wall façade in the deconstructivism architectural style. Its prismatic form is inspired by natural crystal formation. The tower connects well with the existing transportation systems below grade.(Diamond, Opitz, Hicks, Von Neida, \& Herrera, 2006)

\section{SHANGHAI TOWER}

Shanghai Tower is a multi-use building comprised of office, hotel, retail, sky gardens, public space, etc.

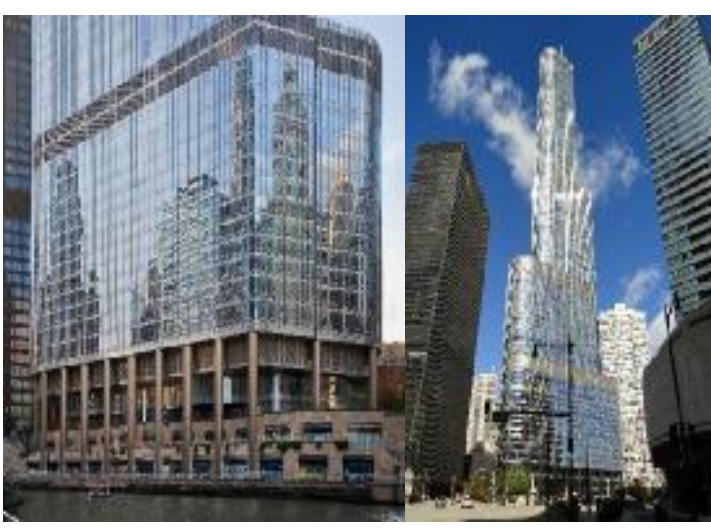

Figure 12 Trump International Hotel and Tower (New York City) Source (www.tripadvisor.com,

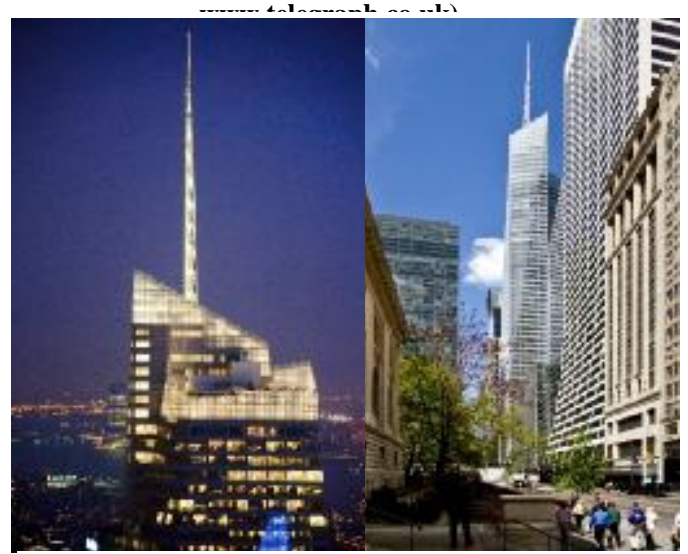

Figure 13 Bank of America tower . Source (http://www.skyscrapercenter.com)

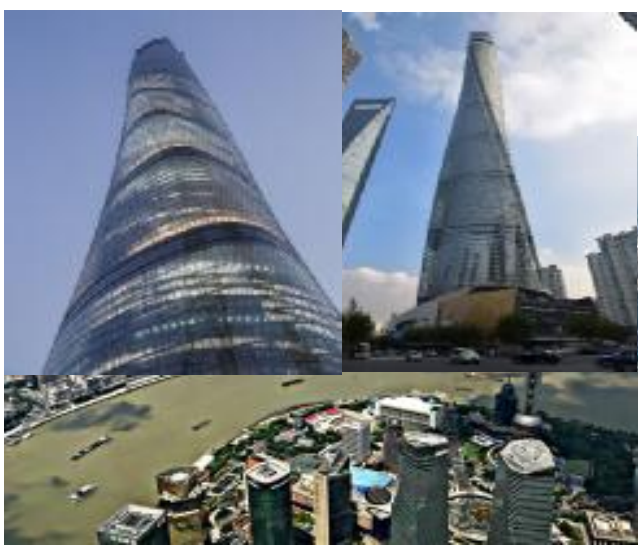

Figure 14 the tower's swiveling, asymmetrical glass façade confuses the organization of wind forces. Source (http://www.skyscrapercenter.com) 
The tower is organized in nine cylindrical buildings stacked on top of e ach oth er and enclosed by a double-skinned glass façade. The Shanghai Tower was designed by the American architectural firm Gensler, with Shanghainese architect Jun Xia leading the design team. (Bryde, Broquetas, \& Volm, 2013) The tower takes the form of nine cylindrical buildings stacked atop each other, totalling 128 floors, all enclosed by the inner layer of the glass facade.

Between that and the outer layer, which twists as it rises, nine indoor zones provide public space for visitors. Each of these nine areas has its own atrium, featuring gardens, cafés, restaurants and retail space, and providing panoramic views of the city.(Seung-hyun, 2010)

The building is one of the most sustainable buildings in the world. The tower's swiveling, asymmetrical glass façade confuses the organization of wind forces and reduces wind loads on the building. The building's spiraling parapet collects rainwater to be used for the tower's heating and air conditioning systems, and wind turbines situated below the parapet generate on-site power. Further, the gardens nestled within the building's façade create a thermal buffer zone while improving indoor air quality.

\section{BAHRAIN WORLD TRADE CENTER}

The Bahrain World Trade Center Designed by the multi-national architectural firm Atkins, construction on the towers was completed in 2008 is first skyscraper in the world to integrate wind turbines into its design. Three different bridges, all of which house a 29-meter turbine, connect two separate towers. These towers face north to capture the winds from the Persian Gulf. The building assumes a sail shape so as to maximize the amount of wind funneled through the towers. The " $\mathrm{S}$ " shape flow is ideal because it ensures that any wind coming within a 45 degree

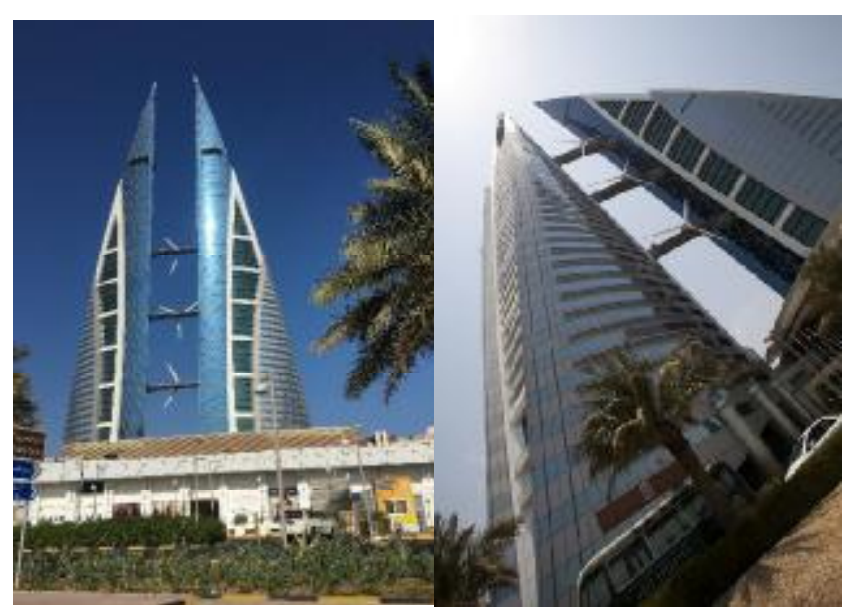

Figure 15 Bahrin WTC the first skyscraper in the world to integrate wind turbines into its design. Source angle to either side will Create a wind stream that is perpendicular to the turbines. These turbines are intended to provide $11 \%$ to $15 \%$ of the towers total power consumption(Foster, Luff, \& Visco, 2008) The two towers are linked via three skybridges, each holding a $225 \mathrm{~kW}$ wind turbine, totalling to $675 \mathrm{~kW}$ of wind power capacity. Each of these turbines

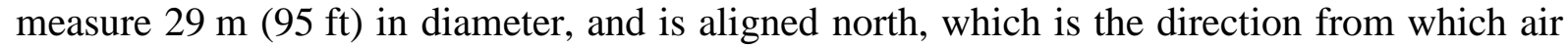
from the Persian Gulfblows in. The sail-shaped buildings on either side are designed to funnel wind through the gap to provide accelerated wind passing through the turbines. $(\mathrm{Ng}$, 2009)

\section{SINGAPORE'S ECOLOGICAL EDITT TOWER}

Currently pending construction in Singapore, the EDITT Tower will be a paragon of "Ecological Design In The Tropics". Designed by TR Hamzah \& Yeang and sponsored by the National University of Singapore, the 26-story high-rise will boast photovoltaic panels, natural ventilation, and a biogas generation plant all wrapped within an insulating living wall that covers half of

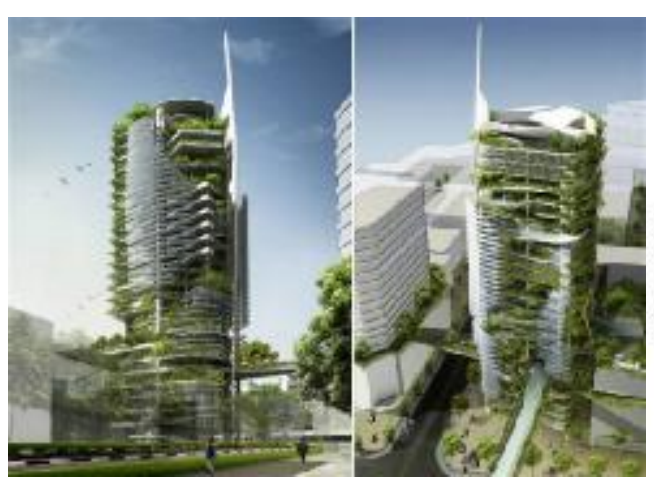

Figure 16 Singapore's Ecological EDITT Tower Source: (www.designbuild-network.com)

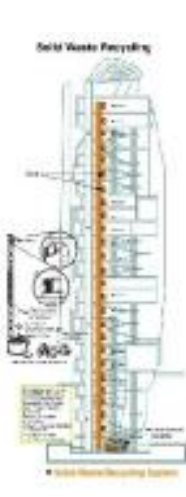


its surface area. The verdant skyscraper was designed to increase its location's bio-diversity and rehabilitate the local ecosystem in Singapore's 'zeroculture' metropolis.(Rodionovskaja \& Dorozhkina, 2018) Approximately half of the surface area of the EDITT Tower will be wrapped in organic local vegetation, and passive architecture will allow for natural ventilation. Publicly accessible ramps will connect upper floors to the street level lined in shops, restaurants and plant life. The building has also been designed for future adaptability, with many walls and floors that can be moved or removed. In a city known for its downpours, the building will collect rainwater and integrate a grey-water system for both plant irrigation and toilet flushing with an estimated 55\% self-sufficiency.(Yeang \& Richards, 2007)

\section{THE PEARL RIVER TOWER (GUANGZHOU, CHINA)}

Pearl River Tower is a 71-story, $309.6 \mathrm{~m}$, clean technology neofuturistic skyscraper The tower's architecture and engineering were performed by Skidmore, Owings \&Merrill . Ground broke on the tower on 2006 and construction was completed in March 2011.(Attia, Hamdy, O'Brien, Carlucci, \& Buildings, 2013) The design of the Pearl River Tower is intended to minimise harm to the environment and it will extract energy from the natural and passive forces surrounding the building. Major accomplishments are the technological integration of form and function in a holistic approach to engineering and architectural design.(Briller \& environment, 2013) The building is designed with energy conservation in mind,

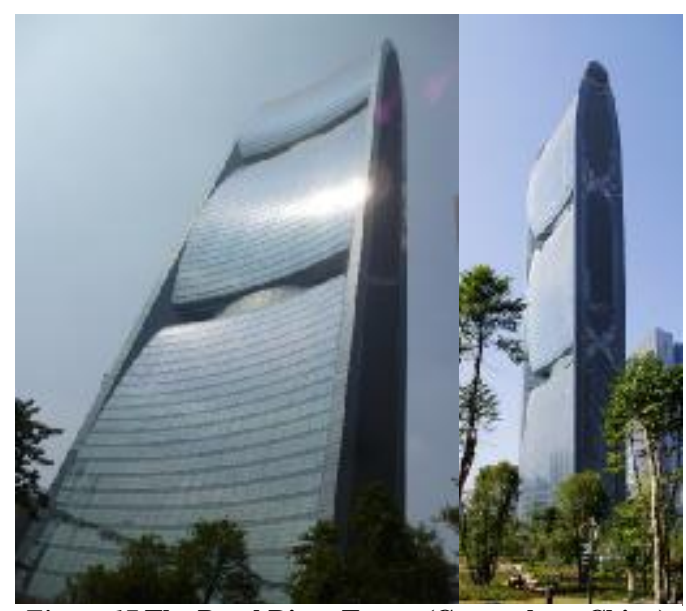

Figure 17 The Pearl River Tower (Guangzhou, China) Source: (www.designbuild-network.com) including wind turbines and solar collectors, photovoltaic cells, underfloor air distribution, and radiant heating and coolingceilings. It is one of the most environmentally friendly buildings in the world.

\section{THE SHARD LONDON BRIDGE}

The Shard's construction began in March 2009; completion was achieved in November 2012. The tower's privately operated observation deck, The View from The Shard, was opened to the public on 1 February 2013 The glass-clad pyramidal tower has 72 habitable floors, with a viewing gallery and openair observation deck on the 72nd floor, at a height of 244 metres $(801 \mathrm{ft})$. designed by Renzo Piano and engineered by Arup and WSP Canto, Designers and developers involved with the tower project were conscious about how to utilize the tower for the advancement of the community and connect it to the urban context, especially in relation to the London Bridge station, which is located close to its site. This culminated in enhancing the station by expanding taxi services, improving pedestrian access, adding bus routes, and improving the overall experience of the station as a public hub for transportation. Other elements of the project indicate a strong penchant towards community. For instance, developers were

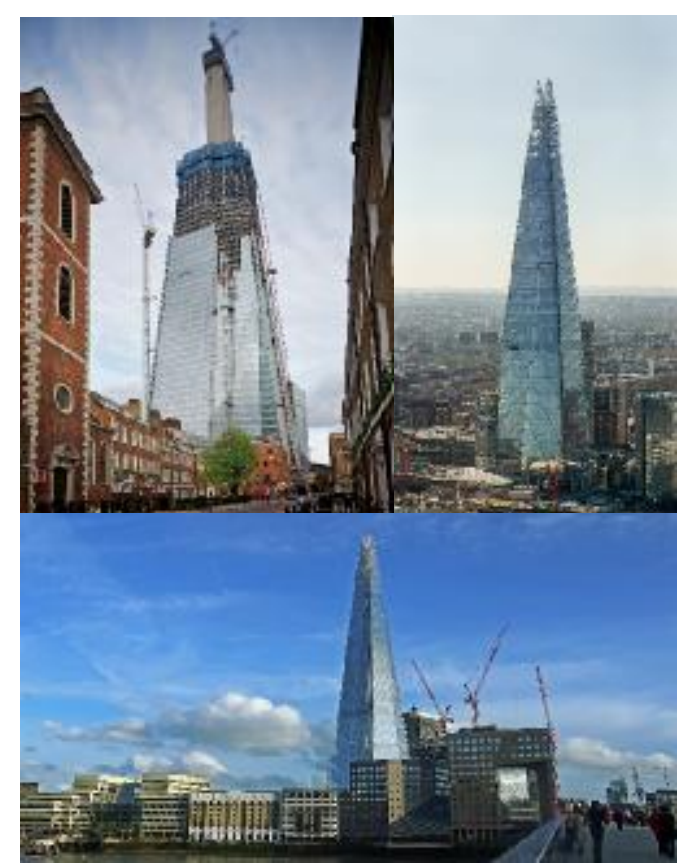

Figure 18 The Shard London Bridge designed by Renzo Piano and engineered by Arup and WSP Canto. Soruce(www.designbuild-network.com) 
adamant about creating jobs for local individuals, not only during the tower's construction, but also for employees who will be working in the finished building.

\section{CIS TOWER (MANCHESTER, ENGLAND)}

The CIS Tower is an office skyscraper on Miller Street in Manchester, England. It was completed in 1962 and rises to 387 feet $(118 \mathrm{~m})$ in height. The Grade II listed building, which houses the Co-operative Banking Group, is Manchester's third-tallest building and the tallest office building in the United Kingdom outside London. The tower remained as built for over 40 years until maintenance issues on the service tower required an extensive renovation which included covering its facade in photovoltaic panels. Currently, the structure can generate more than $10 \%$ of the energy it needs, but it's still a technological

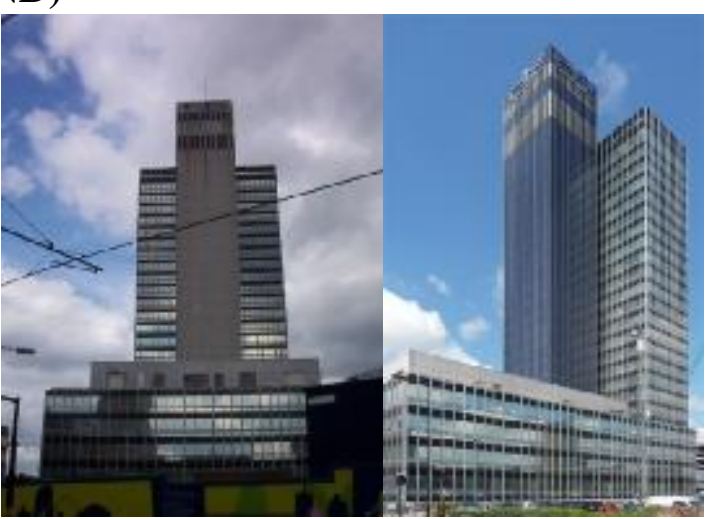

Figure 19 The CIS Tower is an office skyscraper on Miller Street in Manchester, England. Soruce: (www.manchestereveningnews.co.uk) marvel that serves as a great example of integrating renewable energy technologies into preexistent architectural design .(Barrera, 2009)

\section{MARINA BAY SANDS}

Marina Bay Sands is one of two winning proposals for Singapore's first integrated resorts, the other being the Resorts World Sentosa, which incorporates a family-friendly Universal Studios Theme Park (Universal Studios Singapore). The two large-scale resorts were conceived to meet Singapore's economic and tourism objectives for the next decade and will have 30-year casino licenses, exclusive for the first ten years. Bidders were assessed based on four criteria: tourism appeal and contribution, architectural concept and design, development investment, and strength of the consortium and partners. Marina Bay by visionary architect Moshe Safdie, Marina Bay Sands is a 929,000 m2 (10 million sq $\mathrm{ft}$ ), high-density, mixed-use resort that brings together a 2,560 room, 265,000 $\mathrm{m} 2 \quad(2.85$ million sq ft) hotel and convention center; complete with shopping and dining, theaters, museum, and a casino, across the water from Singapore's downtown core. Conceived of as a microcosm of a city rooted in Singapore's culture, climate, and contemporary life, the project anchors the Singapore waterfront, creates a gateway to Singapore, provides a dynamic setting for a vibrant public life, and lifts urban design off above ground. Singapore's Marina Bay Sands is the first MICE venue in Asia Pacific to be awarded the LEED

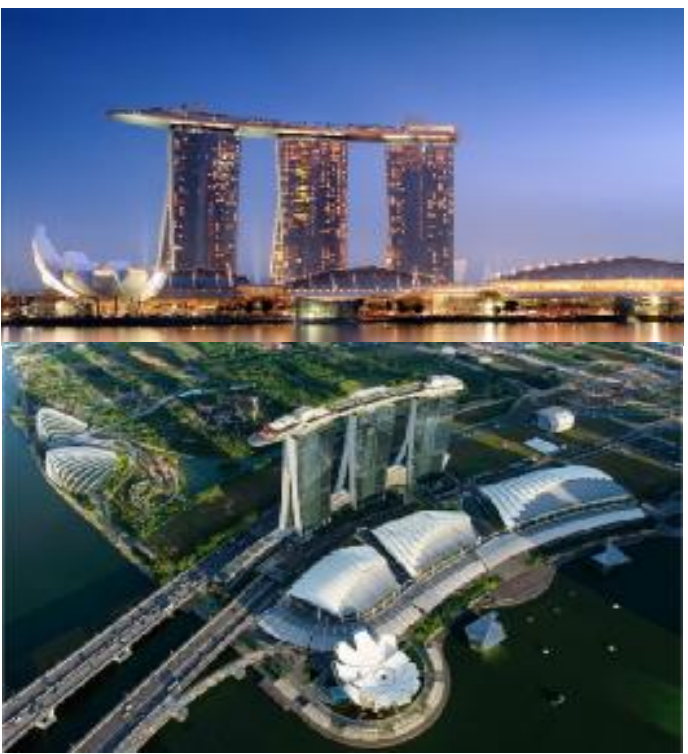

Figure Marina Bay Sands is the first MICE venue in Asia Pacific to be awarded the LEED Platinum for building operations and maintenance of Sands Expo and Convention Centre. Soruce:( /www.marinabavsands.com) Platinum for building operations and maintenance of Sands Expo and Convention Centre. 


\section{CONCLUSION}

Tall buildings have a huge impact on the environment, playing crucial roles in creating the image of the city and offering immense potential to contribute positively to the urban fabric of our cities. A wealth of factors, including scale of construction and scope of programming, make this building typology intricate and unique. Architects assume significant responsibility to pay attention to the design process and innovate ways in which such projects are conceived and realized.

The authors stress that the approach for designing this remarkable building type is to date incomplete and lacking. Moving forward, the strategies for design and development must be comprehensive, integrative, holistic and far more responsive (i.e., socially, psychologically, culturally). Although, the initial cost of integrated green tall buildings may be 5 to 10 percent higher than that of a conventional building, but the long-term lower operational cost makes it justifiable (Seto, Güneralp, \& Hutyra, 2012) for that reason tall buildings need to greater attention with regard to ecological design .

While some researcher's consider tall buildings as "energy-hungry parasites" feeding upon the surrounding ecosystems and natural resources, consuming a huge amounts of discharges into the natural environment, and are therefore un-green, many others researchers confirmed that, skyscrapers can be designed as low-energy ecological, carbon neutral buildings and could be the self-evident ecological building type of the future. Skyscraper designers must consider the entire life cycle of these buildings and view them as not standalone objects but a part of a larger web of interconnected biological and environmental systems. Examples of tall buildings in Asia, united states and the middle east, showcased in the present paper, illustrate movement towards higher levels of environmental performance, urban integration, and place-making, in addition to, these examples figure out a new path for skyscrapers.

\section{REFERENCE'S}

1. Al-Kodmany, K. (2015). Eco-towers: Sustainable cities in the sky: WIT Press.

2. Alexander, C. (1977). A pattern language: towns, buildings, construction: Oxford university press.

3. Ali, M. M., \& Al-Kodmany, K. J. B. (2012). Tall buildings and urban habitat of the 21st century: a global perspective. 2(4), 384-423.

4. Attia, S., Hamdy, M., O’Brien, W., Carlucci, S. J. E., \& Buildings. (2013). Assessing gaps and needs for integrating building performance optimization tools in net zero energy buildings design. 60, 110-124.

5. Baker, W., James, P., Tomlinson, R., \& Weiss, A. J. C. J. (2009). Case Study: Trump International Hotel \& Tower. 3, 16-22.

6. Barrera, V. T. J. E. T. I., http://www. energytrendsinsider. com//05/12/ten-of-thegreenest-skyscrapers-in-the-world. (2009). Ten of the Greenest Skyscrapers in the World.

7. Beaudry, M. H. (1996). Contemporary lodging security: Elsevier.

8. Beedle, L. S. (1988). Second Century of the Skyscraper: Council on Tall Buildings and Urban Habitat: Springer.

9. Blumenfeld, H. (1967). The Modern Metropolis: Its Origins, Growth, Characteristics, and Planning. Selected Essays: Massachusetts Institute of Technology.

10. Briller, D. L. J. S. p. f. e., \& environment, t. (2013). Adapting to a New RealityStrategies for Building Energy Design in a Changing Climate. 33(1), 7-65.

11. Bryde, D., Broquetas, M., \& Volm, J. M. J. I. j. o. p. m. (2013). The project benefits of building information modelling (BIM). 31(7), 971-980. 
12. Bureau, U. S. C. (2013). US and world population clock.

13. Cassen, R. (1987). Our Common Future: Report of the World Commission on Environment and Development. In: JSTOR.

14. Chidiac, S., Catania, E., Morofsky, E., Foo, S. J. E., \& Buildings. (2011). A screening methodology for implementing cost effective energy retrofit measures in Canadian office buildings. 43(2-3), 614-620.

15. Condit, C. W. (1973). The Chicago school of architecture: a history of commercial and public building in the Chicago area, 1875-1925: University of Chicago Press.

16. Cote, A. E. (2008). Fire protection handbook (Vol. 2): NationalFireProtectionAssoc.

17. Council, U. G. B. J. L.-N. V. (2003). Green building rating system for new construction \& major renovations. 2.

18. Craighead, G. (2009). High-rise security and fire life safety: Butterworth-Heinemann.

19. Diamond, R., Opitz, M., Hicks, T., Von Neida, B., \& Herrera, S. (2006). Evaluating the energy performance of the first generation of LEED-certified commercial buildings. Retrieved from

20. Domosh, M. J. J. o. u. h. (1988). The symbolism of the skyscraper: case studies of New York's first tall buildings. 14(3), 320-345.

21. Donnolo, M., Galatro, V., \& Janes, L. J. H. P. B. (2014). Bank of America Tower at One Bryant Park: New York City, NY: Ventilation in Wonderland. 51-58.

22. Drew, C., Nova, K., \& Fanning, K. (2014). The environmental impact of tall vs. small: a comparative study. Paper presented at the Proceedings CTBUH Shanghai Conference, Shanghai Google Scholar.

23. Foster, N., Luff, S., \& Visco, D. J. A. r. f. C. (2008). Green Skyscrapers What is Being Built, and Why. 3840.

24. Gang, J. (2008). Wanted: tall buildings less iconic, more specific. Paper presented at the CTBUH 8th World Congress on Tall \& Green: Typology for a Sustainable Urban Future.

25. Gehl, J. (2011). Life between buildings: using public space: Island press.

26. Gehl, J. J. W. D. (2010). Cities for people Island Press.

27. Giedion, S. (1971). Architecture and the phenomena of transition: the three space conceptions in architecture: Harvard Univ Pr.

28. Gifford, R. J. A. s. r. (2007). The consequences of living in high-rise buildings. 50(1), 2-17.

29. Gonçalves, J. C. S. (2010). The environmental performance of tall buildings: Routledge.

30. Gültekin, A., \& Dikmen, C. (2006). Analysis of Ecological Design Criteria in Architectural Design Process. Paper presented at the National Ecology and Environment Congres, Izmir.

31. Gültekin, A. B., \& Yavaşbatmaz, S. J. G. (2013). Sustainable design of tall buildings. 65(05.), 449-461.

32. Günel, M. H., \& Ilgin, H. E. (2014). Tall buildings: structural systems and aerodynamic form: Routledge.

33. Hall Jr, J. R. J. Q., MA: National Fire Protection Association. (2005). Manufactured home fires.

34. Khan, F. R. (1972). Influence of design criteria on selection of structural systems for tall buildings. Paper presented at the Proceedings of the Canadian Structural Engineering Conference.

35. Knoke, M. J. P. o. A. M. (2006). Managing Editor, CPP. High-rise structures: life safety and security considerations.

36. Krier, L. (2009). The architecture of community: Island Press. 
37. Kuhlman, T., \& Farrington, J. J. S. (2010). What is sustainability? , 2(11), 3436-3448.

38. Larsson, N. J. P., \& Environment, O. I. I. f. a. S. B. (2009). Very tall buildings and sustainability.

39. Madanipour, A. J. P. P. (2010). The limits of scientific planning: Doxiadis and the Tehran Action Plan. 25(4), 485-504.

40. Milne, M. J., \& Gray, R. J. J. o. b. e. (2013). W (h) ither ecology? The triple bottom line, the global reporting initiative, and corporate sustainability reporting. 118(1), 1329.

41. Ng, E. (2009). Designing high-density cities: for social and environmental sustainability: Routledge.

42. Oldfield, P. (2012). Tall buildings and sustainability. University of Nottingham,

43. Prezza, M., Amici, M., Roberti, T., \& Tedeschi, G. J. J. o. c. p. (2001). Sense of community referred to the whole town: Its relations with neighboring, loneliness, life satisfaction, and area of residence. 29(1), 29-52.

44. Pruetz, R. (2017). Lasting Value: Open space planning and preservation successes: Routledge.

45. Rodionovskaja, I., \& Dorozhkina, E. (2018). "Green architecture" as an Onnovative Direction of Construction. Paper presented at the IOP Conference Series: Materials Science and Engineering.

46. Say, C., Wood, A. J. C. o. T. B., \& Journal, U. H. (2008). Sustainable rating systems around the world. 2, 18-29.

47. Scott, F. D. E. (2007). Architecture or techno-utopia: politics after modernism: MIT press Cambridge, MA.

48. Seto, K. C., Güneralp, B., \& Hutyra, L. R. J. P. o. t. N. A. o. S. (2012). Global forecasts of urban expansion to 2030 and direct impacts on biodiversity and carbon pools. 109(40), 16083-16088.

49. Seung-hyun, W. J. S. (2010). INTEGRATED DESIGN OF TECHNOLOGY AND CREATIVE IMAGINATION ON SUPERTALL BUILDING. (512), 28-31.

50. Short, M. J. P. H. (2004). Regulating the impact of proposals for new tall buildings on the built heritage. 26(3), 4-10.

51. Sinclair, B. R. J. C., \& Systems. (2015). Integration| innovation| inclusion: Values, variables and the design of human environments. 46(6-7), 554-579.

52. Sneddon, C., Howarth, R. B., \& Norgaard, R. B. J. E. e. (2006). Sustainable development in a post-Brundtland world. 57(2), 253-268.

53. Swarr, T. E., Legarth, J. B., \& Huang, E. A. (1999). Implementation of Design for Environment at a Diversified OEM. Paper presented at the Electronics and the Environment, 1999. ISEE-1999. Proceedings of the 1999 IEEE International Symposium on.

54. Thornton, B. A., Rosenberg, M. I., Richman, E. E., Wang, W., Xie, Y., Zhang, J., . . Liu, B. (2011). Achieving the 30\% goal: Energy and cost savings analysis of ASHRAE Standard 90.1-2010. Retrieved from

55. Van Horne, J. C., \& Wachowicz, J. M. (2005). Fundamentals of financial management: Pearson Education.

56. White, N., Willensky, E., \& Leadon, F. (2010). AIA Guide to New York City: Oxford University Press.

57. Wood, A. J. I. G. S. (2013). A global analysis of tall, supertall and megatall buildings. $1,25-29$. 
58. Yeang, K. (2008). Ecoskyscrapers and Ecomimesis: New tall building typologies. Paper presented at the Proceedings of the 8th CTBUH World Congress on Tall \& Green: Typology for a Sustainable Urban Future, Dubai, UAE.

59. Yeang, K., \& Richards, I. (2007). Eco Skyscrapers I (Vol. 1): Images Publishing. web sites

https://www.britannica.com/place/Mecca

https://www.marinabaysands.com/shopping/7-eleven.html

https://en.wikipedia.org/wiki/Skyscraper

http://www.ctbuh.org/criteria/

https://www.skyscrapercenter.com/

https://www.archdaily.com/915210/ctbuh-2019-international-student-tall-building-designcompetition

https://www.thoughtco.com/skyscraper-tall-buildings-deconstructed-177330

https://www.nbmcw.com/interviews/29183-ctbuh-india-has-to-go-vertical.html

http://competitions.archi/competition/ctbuh-2019-international-student-tall-building-designcompetition/

https://bustler.net/competitions/6656/ctbuh-2019-international-student-tall-building-designcompetition

http://www.dubaifountain.info/ctbuh-criteria-for-defining-and-measuring-tall-buildings/

https://www.designingbuildings.co.uk/wiki/Megatall

https://newatlas.com/ctbuh-best-tall-buildings-2012/22942/

https://architexturez.net/pst/az-cf-191422-1554952962

https://images.adsttc.com/submissions/opportunities/pdf_file/2330/CTBUH2018Competition

Brief.pdf?utm medium $=$ website \&utm source $=$ archdaily.com

https://pdfs.semanticscholar.org/b412/75f201bf2a70d71a5822bd0abf6f7dff5930.pdf

http://ibc.org.in/Committees/PlanningDesignBuildings

https://www.acronymattic.com/Council-on-Tall-Building-and-Urban-Habitat-(CTBUH).html

http://www.urban-hub.com/buildings/02-15-recording-tall-tales-the-state-of-high-rises/

https://www.dezeen.com/2019/04/12/ctbuh-awards-salesforce-tower-san-francisco/

https://www.technologybreakingnews.com/tag/buildings-hong-kong-skyline/ 